\title{
Monialaisten maatilojen tuloverojärjestelmät
}

\author{
Sami Ovaska \\ MTT Taloustutkimus,PL 3, 00411 Helsinki, sami.ovaska@mtt.fi
}

\section{Johdanto}

Yhä useammalla maatilalla osa toimeentulosta saadaan perinteisen maataloustuotannon ulkopuolelta. Yrityskoon kasvun ohella yhtenä strategiavaihtoehtona maatalouden toimintaympäristön muutoksessa on nähty tulorakenteen monipuolistaminen (Niemi ym. 1995, s. 165). Eräs tulorakenteen monipuolistamiskeino on muun yritystoiminnan harjoittaminen maatilalla varsinaisen maatalouden lisäksi. Maatiloilla harjoitettava muu yritystoiminta on melko yleinen ilmiö, sillä vuonna 2000 sitä harjoitettiin reilulla neljäsosalla Suomen maatiloista.

Maatalouden verotusta, samoin kuin tulorakenteen monipuolistamista, on tutkittu vähän. Yritystoiminnan tuloverotuksessa keskeisellä sijalla yritysmuodon ohella on toimintaan sovellettava tuloverolaki. Maatalouden tuloverotuksessa sovelletaan maatilatalouden tuloverolakia (MVL), joka sisältää verotettavan tuloksen laskentasäännöt. Elinkeinotoiminnan verotettava tulos lasketaan puolestaan elinkeinoverolain (EVL) mukaan. Tällöin mielenkiintoista verotuksen näkökulmasta on maatiloilla varsinaisen maatalouden lisäksi harjoitettava muu yritystoiminta, sillä ei ole olemassa selviä säännöksiä siitä, milloin kyseistä toimintaa verotetaan varsinaisen maatalouden ohella MVL:n mukaan ja milloin EVL:n mukaan erillisenä liikkeenä. Valtaosaa maatiloilla harjoitetusta muusta yritystoiminnasta verotettiin vuonna 2000 varsinaisen maatalouden ohella MVL:n mukaan, jonka osuus oli $65 \%$ (TIKE 2001, s. 6).

Yrittäjän kannalta ei kuitenkaan ole yhdentekevää, kumman verolain mukaan toiminnan tulos lasketaan ja toisaalta missä yritysmuodossa toimintaa harjoitetaan. Tämä johtuu MVL:n ja EVL:n sisältöeroista ja yritysmuodon vaikutuksesta jaettaessa verotettavaa tulosta yrittäjälle. Niiden lisäksi tulolähdetulkinta, eli tapahtuuko verotus MVL:n vai EVL:n mukaan, aiheuttaa yrittäjälle myös muita vaikutuksia. Tutkimuksen tavoite oli maatilalla harjoitetun muun yritystoiminnan verotuksen tutkiminen. Tutkimuksen tavoitteena oli selvittää:

1. Miten tilalla muuta yritystoimintaa harjoittavan viljelijäpariskunnan tuloverorasitus muuttuu, jos muuta yritystoimintaa verotetaan EVL:n mukaan erillisenä liikkeenä verrattuna tilanteeseen, jossa sitä verotetaan varsinaisen maatalouden ohella MVL:n mukaan.

2. Mitä muita vaikutuksia viljelijäpariskunnalle aiheutuu, jos tilan muuta yritystoimintaa verotetaan EVL:n mukaan erillisenä liikkeenä verrattuna tilanteeseen, jossa sitä verotetaan varsinaisen maatalouden ohella MVL:n mukaan.

\section{Aineisto ja menetelmät}

Tutkimusaineistona käytettiin MTT Taloustutkimuksen niiden kannattavuuskirjanpitotilojen tietoja vuosilta 1998-2000, joilla harjoitettiin varsinaisen maatalouden ohella myös muuta yritystoimintaa. Kirjanpitoaineistosta muodostettiin edustavat tilat, jotka koostuivat kahdesta pääosasta; tilan varsinaisesta maataloudesta sekä tilan muusta yritystoiminnasta. Muun yritystoiminnan toimialat olivat koneurakointi, maatilamatkailu ja elintarvikkeiden jatkojalostus, joten edustavia tiloja muodostettiin yhteensä kolme. Kannattavuuskirjanpidossa tilan varsinaiselle maataloudelle sekä muulle yritystoiminnalle laaditaan tuloslaskelmat sekä taseet erikseen, vaikka molempia verotettaisiin MVL:n mukaan. Tämä tilan muun yritystoiminnan kirjanpidollinen eriyttäminen varsinaisesta maataloudesta mahdollisti kahdesta pääosasta muodostuvien edustavien tilojen rakentamisen. Edustavat tilat muodostettiin kuvaamaan Etelä-Suomessa A- ja Btukialueilla sijaitsevaa monialaista viljatilaa, jolla harjoitetaan koneurakointia, maatilamatkailua tai elintarvikkeiden jatkojalostusta.

Edustavien tilojen lisäksi muodostettiin kolme lakimallia, jotka sisälsivät tuloverotuksen laskentasäännöt eri laskentavaihtoehdoissa. Lakimallit koostuivat viidestä tuloverotuksen vaiheesta. Ne olivat jaettavan yritystulon määrittäminen joko MVL:n tai EVL:n perusteella, nettovarallisuuden määritys, nettovarallisuuden perusteella tehtävä jaettavan yritystulon jako pääoma- ja ansiotulo-osuuksiin sekä yksityisen maatalouden- ja liikkeenharjoittajan osalta osuuksien jako puolisoiden kesken. Tämän jälkeen määritettiin puolisoiden maksamat tuloverot pääoma- ja ansiotuloista.

Ensimmäisessä vaihtoehdossa edustavien tilojen kaikkea yritystoimintaa harjoitettiin yksityisenä 
maataloudenharjoittajana ja verotettiin MVL:n mukaan. Toisessa vaihtoehdossa tilan muuta yritystoimintaa harjoitettiin yksityisliikkeenä ja verotettiin EVL:n mukaan. Kolmannessa vaihtoehdossa tilan muuta yritystoimintaa harjoitettiin osakeyhtiönä ja verotettiin EVL:n mukaan. Osakeyhtiön oletettiin jakavan koko verotettavan tuloksensa osinkoina yritysmuotojen vertailukelpoisuuden vuoksi. Kaikissa vaihtoehdoissa tilan varsinaista maataloutta eli viljanviljelyä verotettiin MVL:n mukaan yksityisenä maataloudenharjoittajana, joten tulolähde- ja yritysmuotomuutokset koskivat vain tilan muuta yritystoimintaa.

Tutkimusmenetelmänä käytettiin staattista aineistoon perustuvaa mikrosimulointia, joka koostui kirjanpitoaineistosta muodostetuista toimialoittaisista edustavista tiloista sekä tuloverotuksen laskentasäännöt sisältävistä lakimalleista. Menetelmässä lakimallien sisältämät tuloverotuksen laskentasäännöt kohdistettiin toimialoittaisille edustaville tiloille, jolloin voitiin simuloida viljelijäpariskunnan tuloverotusta.

\section{Tulokset ja tulosten tarkastelu}

Maatilatalouden tuloverolain ja elinkeinoverolain pääperiaatteet olivat lähellä toisiaan, joten jaettavan yritystulon määrissä niiden välillä ei syntynyt merkittäviä eroja. Eroja varsinaisissa menojen vähennysoikeuksissa, eli onko meno vähennyskelpoinen tulosta vai ei, oli vähän. Lakien suurimmat erot liittyivät menoerien jaksottamissääntöihin eli elinkeinoverolain suoriteperusteisuuteen, maatilatalouden tuloverolain maksuperusteisuuteen, rakennuspoistoihin sekä varausmahdollisuuksiin.

MVL:n maksuperusteisuus tarkoittaa menon tai tulon lukemista sen verovuoden kuluksi tai tuotoksi, jona maksu on suoritettu tai tulo saatu. Sen avulla voidaan tehokkaasti jaksottaa menoja sekä tuloja tulontasauksen kannalta edullisella tavalla. EVL-verotuksessa on pääsääntönä suoriteperiaate, jonka mukaan meno syntyy tuotannontekijöitä vastaanotettaessa ja tulo luovutettaessa suorite. Varsinaisella maksuajankohdalla ei siten ole merkitystä eikä sitä voida käyttää tulontasauksessa hyödyksi. MVL.verotuksessa talousrakennusten poisto on enintään $10 \%$ ja asuin- sekä toimistorakennusten poisto enintään $6 \%$ menojäännöksestä. EVL:n vastaavat poistoprosentit ovat $7 \%$ ja $4 \%$. MVL-verotuksessa voidaan tehdä enintään $40 \%$ :n tasausvaraus maatilan maatalouden puhtaasta tulosta ennen varauksen vähentämistä. Varaus saa olla suuruudeltaan enintään $13500 €$ ja sen tulee olla vähintään $800 €$. Tasausvaraus voidaan tulouttaa suoraan maatalouden tuloksi tai sen avulla voidaan tehdä käyttöomaisuudesta poistoja ennakkoon vähentämällä se käyttöomaisuuden poistopohjasta (MVL 10a §). EVL-verotuksessa ei ole käytössä tasausvarausta. EVL-verotuksessa käytetään toimintavarausta, mutta osakeyhtiöillä ei ole siihen oikeutta. Verovuonna tehtyjen sekä aikaisemmin tehtyjen purkamattomien varausten yhteismäärä ei saa ylittää $30 \%$ tilikautena maksetuista palkoista. (EVL 46a §). Toimintavarausta ei voida purkaa käyttöomaisuusinvestointeihin toisin kuin tasausvaraus. Tilan muun yritystoiminnan verottaminen elinkeinotoimintana aiheuttaa myös muita vaikutuksia, kuten elinkeinotoiminnan osalta kirjanpitovelvollisuuden alkamisen, MYELvakuutuksen vaihtumisen YEL-vakuutukseksi ja koko tilan siirtymisen arvonlisäverotuksessa kuukausimenettelyyn.

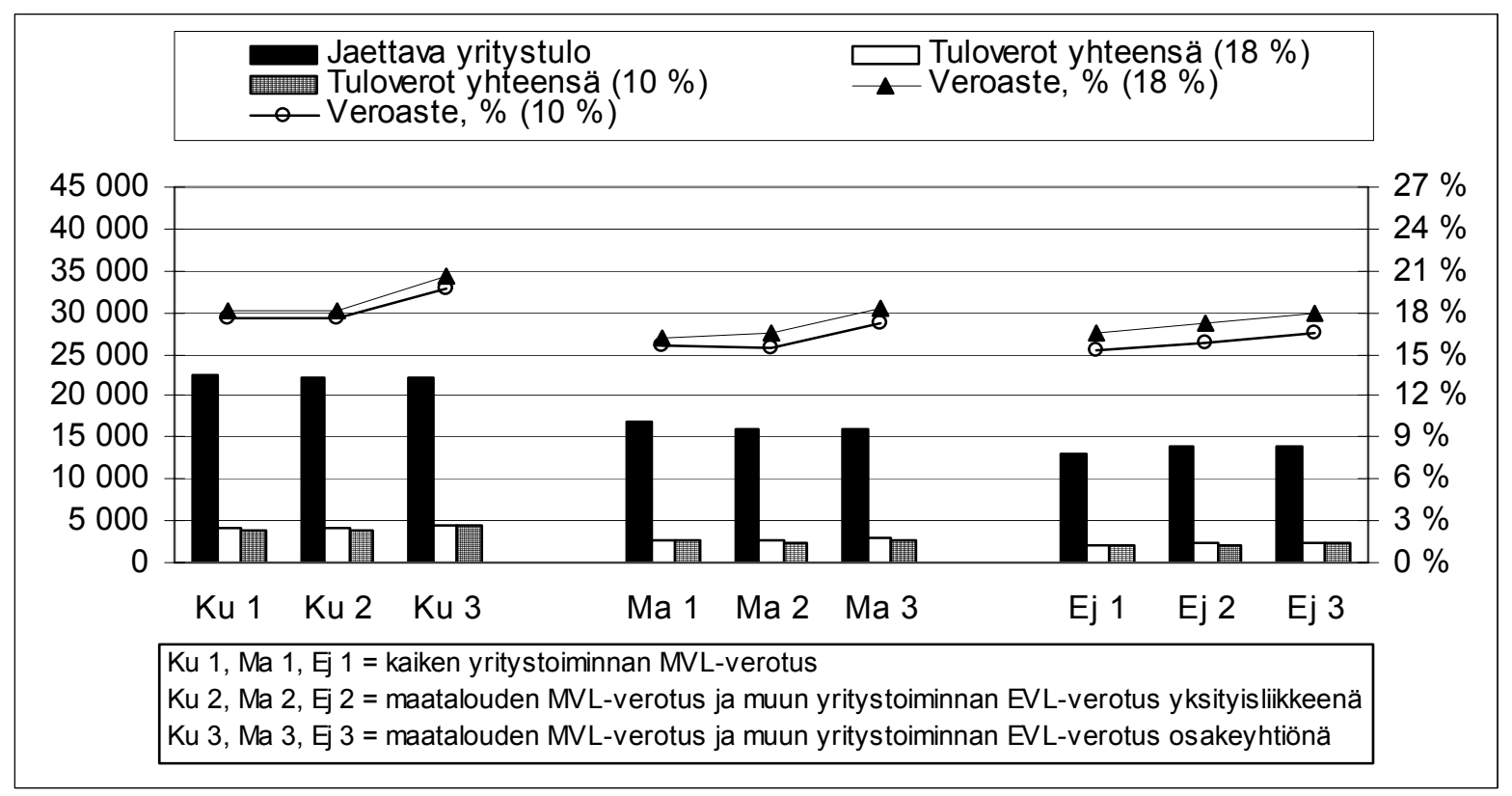

Kuva 1. Tuloverot toimialoittain. $\mathrm{Ku}=$ koneurakointitila, $\mathrm{Ma}=$ maatilamatkailutila, $\mathrm{Ej}=\mathrm{elintarvikkeiden}$ jatkojalostus- 
tila. 10/18 \% on verotuksessa valittu pääomatulo-osuus.

Kuvassa 1 on esitetty edustavilla tiloilla muodostunut jaettava yritystulo, viljelijäpariskunnan tuloverot ja veroaste. Muun yritystoiminnan harjoittaminen EVL-osakeyhtiönä nosti viljelijäpariskunnan veroastetta kaikilla toimialoilla. Toimialoittain tarkasteltuna suurimmat tulolähdemuutoksista (MVL/EVL) ja yritysmuotomuutoksista johtuvat vaikutukset aiheutuivat koneurakointitilalle. Harjoitettaessa koneurakointitilalla kaikkea yritystoimintaa, sekä viljanviljelyä että koneurakointia, MVL:n mukaan yksityisenä maataloudenharjoittajana ja valittaessa pääomatulo-osuudeksi $10 \%$ viljelijäpariskunnan veroaste oli $17,6 \%$. Harjoitettaessa koneurakointia EVL-osakeyhtiönä ja viljanviljelyä yksityisenä maataloudenharjoittajana MVL:n mukaan sekä valittaessa maatalouden pääomatulo-osuudeksi $18 \%$ viljelijäpariskunnan veroaste oli 20,7 \%,. Siten veroasteen nousu oli enimmillään 3,1 \%-yksikköä.

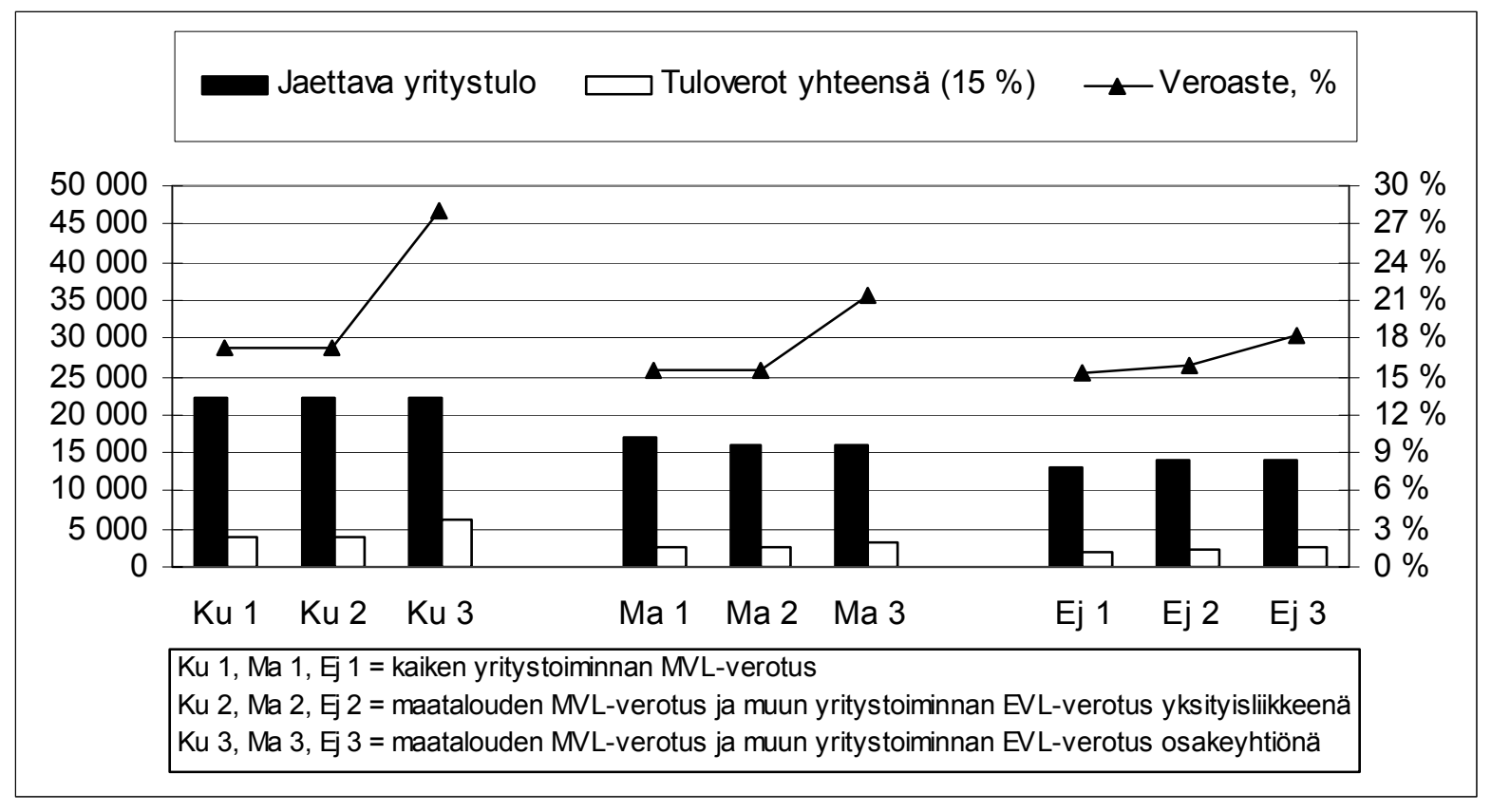

Kuva 2. Verotyöryhmän ehdotusten vaikutukset toimialoittain. $\mathrm{Ku}=$ koneurakointitila, $\mathrm{Ma}=$ maatilamatkailutila, Ej=elintarvikkeiden jatkojalostustila. $10 / 18 \%$ on verotuksessa valittu pääomatulo-osuus.

Lakimallien sisältämiin tuloverotuksen laskentasääntöihin tehtiin muutoksia valtiovarainministeriön verotyöryhmän (Arvelan työryhmä) syksyllä 2002 ehdottamien muutosten pohjalta. Vertaamalla kuvaa 2 kuvaan 1 nähdään tuloverotusta koskevien muutosehdotusten vaikutusten suuntaa. Työryhmän ehdotuksista huomioitiin yhtiöveron hyvityksestä luopuminen sekä yhteisövero- että pääomatuloverokannan alentuminen $25 \%$ :iin. Tällöin osinkoihin kohdistui 43,75\%:n kokonaisvero. Yksityisen maatalouden- ja elinkeinonharjoittajan osalta huomioitiin pääomatulo-osuuden muuttuminen $15 \%$ :iin nykyisen 10 tai $18 \%$ :n sijaan. Poistokäytäntöjä ei muutettu, joten jaettava yritystulo säilyi ennallaan.

Ehdotetut muutokset nostivat viljelijäpariskunnan veroastetta kaikilla toimialoilla harjoitettaessa muuta yritystoimintaa EVL-osakeyhtiönä. Eniten veroaste nousi koneurakointitilalla, jolla nousu oli enimmillään 8,3\%-yksikköä. Maatilamatkailutilalla nousu oli 4,1 \%-yksikköä ja elintarvikkeiden jatkojalostustilalla 1,7 \%-yksikköä. Muilla yritysmuodoilla vaikutukset olivat vähäisiä.

\section{Johtopäätökset}

Hallituksen kannanotossa syksyllä 2003 esitettiin muutoksia Arvelan työryhmän esityksen pohjalta yritysja pääomatuloverotukseen. Kannanotossa luovutaan yhtiöveron hyvityksestä ja siirrytään osittaiseen osinkojen kahdenkertaiseen verotukseen. Yhteisö- ja pääomaverokanta eriytetään $26 \%$ ja 28 \%:iin nykyisestä $29 \%$ :sta. Muiden kuin pörssiyhtiöiden osingoista on verovapaata $9 \%$ nettovarallisuudesta, jonka ylittävästä osuudesta $70 \%$ verotetaan ansiotulona. Verovapaiden osinkojen enimmäismäärä on $90000 €$ vuodessa. Tämän ylittävästä osasta osingosta 70 \% verotetaan pääomatulona (VM 2003). Hallituksen kannanoton ja tutkimuksessa käytetyn Arvelan työryhmän esitykset poikkeavat jonkin verran toisistaan. Yhteisöverokannan eriyttäminen pääomaverokantaa alemmalle tasolle saattaa kannustaa yrittäjää jättämään aikai- 
sempaa enemmän voittovaroja osakeyhtiöön kasvattamaan nettovarallisuutta osingonjaon sijaan. Eroista huolimatta molempien esitysten suunta on sama. Osakeyhtiössä toimiminen suhteessa muihin yritysmuotoihin heikkenee osinkoverotuksen kiristymisen johdosta.

Tutkimuksen perusteella EVL ei sisältänyt sellaisia tekijöitä, joiden perusteella maatilan muu yritystoiminta kannattaisi saada MVL-verotuksesta EVL-verotukseen. Tutkimustiloilla osakeyhtiö oli lisäksi epäedullisin muun yritystoiminnan harjoittamismuoto. Hallituksen kannanotossa osakeyhtiöiden suhteellinen asema heikkenee edelleen. Tämän perusteella tilan kaiken yritystoiminnan, sekä varsinaisen maatalouden että muun yritystoiminnan, harjoittaminen MVL:n mukaan yksityisenä maataloudenharjoittajana näytti parhaalta vaihtoehdolta.

\section{Kirjallisuus}

EVL 24.6.1968/360. Laki elinkeinotulon verottamisesta. Annettu Helsingissä 24.6.1968. Viitattu 5.9.2002. Saatavissa internetistä: http://www.finlex.fi/lains/index.html.

MVL 18.12.1967/543. Maatilatalouden tuloverolaki. Annettu Helsingissä 18.12.1967. Viitattu 19.9.2002. Saatavissa internetistä: http://www.finlex.fi/lains/index.html.

Niemi, J., Linjakumpu, H. \& Lankoski, J. 1995. Maatalouden alueellinen rakennekehitys vuoteen 2005. MTTL tiedonantoja 204. Helsinki: MTTL. 184 s.

TIKE 2001. Maatalouslaskenta 2000. Muu yritystoiminta maatiloilla. Maa- ja metsätalousministeriön tietopalvelukeskuksen julkaisu 4. Helsinki: TIKE. $26 \mathrm{~s}$.

VM 2003. Yritys- ja pääomaverotuksen uudistus. Viitattu: 1.12.2003. Saatavissa internetistä:

http://www.vm.fi/vm/liston/page.lsp?r=44956\&l=fi\&menu=2622 